\title{
PENGEMBANGAN PERANGKAT PERKULIAHAN INOVATIF BERDASARKAN TINGKAT OTONOMI PEBELAJAR PADA PERKULIAHAN FISIKA DASAR
}

\author{
Abdul Salam M.1), Prabowo' ${ }^{2)}$, Z.A. Imam Supardi') \\ 1)Universitas Lambung Mangkurat Banjarmasin \\ ${ }^{2), 3)}$ Dosen Pascasarjana Prodi Pendidikan Sains Universitas Negeri Surabaya
}

\begin{abstract}
This research was intended to produce the innovative instructional materials based on the learner autonomy levels on fundamental physics lecture and also to describe the feasibility of the materials. This research was conducted in two stages. The first stage was the preparation intended to produce the innovative instructional materials. The second stage was the instructional implementation in a classroom by using the pretest and posttest group design. The data of research results showed that the developed instructional materials were declared valid according to the expert judgment with good category on the whole. The developed instructional materials also fulfilled the practical criteria based on (a) the application of the lesson plan in classroom reaching $100 \%$ with the quality of very good category, and (b) the students' activities were suitable with the requirement of every stage of the lesson plan. Furthermore, the developed instructional materials were also declared effective based on (a) the assessment of the students' learning outcome giving the learning mastery of $100 \%$, while the mastery of achievement indicator of basic competence being $100 \%$, and (b) the students' response to the instruction in the forms of interest and motivation including the aspects of attention, relevance, self-confidence, and satisfaction, all of which being of good category. Based on the findings of the research, it can be concluded that the developed instructional materials based on the learner autonomy levels were declared feasible (valid, effective, and practical) to be used on fundamental physics lecture.
\end{abstract}

Keywords: Instructional materials development, innovative instruction, learner autonomy levels.

\begin{abstract}
Abstrak: Penelitian ini bertujuan untuk menghasilkan perangkat perkuliahan inovatif berdasarkan tingkat otonomi pebelajar pada perkuliahan fisika dasar dan juga untuk mendeskripsikan kelayakan perangkat perkuliahan tersebut. Penelitian ini dilaksanakan dalam dua tahap. Tahap pertama adalah persiapan; bertujuan untuk menghasilkan perangkat. Tahap kedua adalah implementasi perkuliahan di kelas yang menggunakan rancangan pretest and posttest group design. Data hasil penelitian menunjukkan bahwa perangkat perkuliahan yang dikembangkan dinyatakan valid berdasarkan hasil penilaian pakar yang kesemuanya berkategori baik. Perangkat perkuliahan hasil pengembangan juga memenuhi kriteria praktis berdasarkan (a) keterlaksanaan RPP sebesar $100 \%$ dengan kualitas keterlaksanaan berkategori sangat baik, dan (b) aktivitas mahasiswa sesuai dengan tuntutan dari setiap tahapan perkuliahan yang direncanakan. Lebih lanjut perangkat perkuliahan yang dikembangkan juga dinyatakan efektif berdasarkan (a) hasil belajar mahasiswa yang memberikan ketuntasan sebesar 100\%, dengan ketuntasan indikator ketercapaian kompetensi dasar $100 \%$, dan (b) respon mahasiswa terhadap perkuliahan berupa minat dan motivasi yang meliputi aspek perhatian, relevansi, kepercayaan diri, dan kepuasan, yang semuanya berkategori baik. Berdasarkan temuan-temuan hasil penelitian, dapat disimpulkan bahwa perangkat perkuliahan berdasarkan tingkat otonomi pebelajar yang dikembangkan dinyatakan layak (valid, efektif dan praktis) untuk digunakan dalam perkuliahan fisika dasar.
\end{abstract}

Kata kunci: Pengembangan perangkat perkuliahan, perkuliahan inovatif, otonomi pebelajar.

\section{PENDAHULUAN}

Undang-Undang No. 20 tahun 2003 tentang Sistem Pendidikan Nasional dan Undang-undang No. 12 tahun 2012 tentang Pendidikan Tinggi secara jelas telah memberikan beberapa penekanan dalam konsep pendidikan kita. Pertama, pendidikan adalah usaha sadar dan terencana, yang berarti bahwa proses yang dilakukan di dalam kelas harus dengan pertimbangan dan perencanaan matang dalam upaya pencapaian tujuan. Kedua, pendidikan harus menyeimbangkan antara proses dan hasil belajar. Ketiga, pendidikan harus berorientasi pada peserta didik agar aktif mengembangkan potensi dirinya. Keempat, proses pendidikan berujung pada pembentukan sikap, pengembangan kecerdasan atau intelektual, dan pengembangan keterampilan (Sanjaya, 2011).

Fakta di lapangan, khususnya di daerah Kalimantan Selatan menunjukkan bahwa proses pembelajaran/perkuliahan di kelas masih jauh dari harapan/amanah undang-undang. Berdasarkan pengalaman peneliti, umumnya perkuliahan di kelas (khususnya di PMIPA-FKIP Universitas Lambung Mangkurat) masih belum dilengkapi dengan perangkat perkuliahan yang memadai. Proses perkuliahan masih 
didominasi oleh dosen (teacher centered) dengan pola: penyampaian informasi (metode ceramah) tentang konsep, teori, dan rumus yang diikuti contoh soal. Mahasiswa sebagai subjek belajar lebih banyak diposisikan sebagai pendengar dan belum diberi kesempatan untuk lebih terlibat secara aktif dalam proses pemerolehan pengetahuan (kurang otonom). Penuntun praktikum yang digunakan di laboratonium sudah sangat lengkap dan terstruktur sehingga tidak melibatkan mahasiswa dalam keterampilan proses sains secara lengkap.

Program Studi Pendidikan Fisika FKIP Unlam sebagai satu-satunya lembaga pencetak guru fisika di Kalimantan Selatan diharapkan berperan secara maksimal dalam mengatasi permasalahan di atas melalui inovasi dalam perkuliahan. Prabowo (2000) menyatakan bahwa dalam proses pembelajaran fisika, peserta didik hendaknya diarahkan untuk terbiasa bekerja layaknya seorang saintis melalui kegiatan penemuan dan inkuiri. Dukungan antara teori dan praktek serta pengintegrasiannya dalam proses pembelajaran menjadi sebuah kebutuhan untuk segera dilaksanakan. Bagi LPTK hal ini menjadi sangat penting, sebab menurut Direktorat Jenderal Pendidikan Tinggi Depdikbud (1991), gaya mengajar guru-guru fisika di SLTA didominasi oleh gaya mengajar dosennya pada saat mereka masih belajar di Perguruan Tinggi.

Salah satu upaya untuk meningkatkan kualitas proses dan hasil belajar mahasiswa adalah dengan mengembangkan perangkat perkuliahan inovatif. Perangkat perkuliahan yang dikembangkan harus mampu melibatkan mahasiswa secara aktif dan bertahap untuk membangun atau menemukan pengetahuan baru. Pengetahuan baru tersebut dapat berupa konsep-konsep, prinsip-prinsip atau teori-teori fisika, serta mampu memecahkan masalah yang berkaitan dengan gejala/fenomena fisika dan atau produk teknologi.

Proses perkuliahan yang bertahap dalam pengertian ini adalah dalam hal pemberian otonomi kepada pebelajar (mahasiswa). Howe \& Jones (1993) membagi otonomi pebelajar dalam tiga tingkatan. Pada tingkat otonomi pertama dipilihlah pembelajaran langsung untuk menyampaikan pengetahuan deklaratif serta melatihkan keterampilan prosedural, utamanya keterampilan dalam memecahkan masalah melalui kegiatan penyelidikan. Pada proses pembelajaran ini tingkat otonomi pebelajar masih rendah dan perkuliahan masih berpusat pada guru. Pada tingkatan kedua digunakan pembelajaran penemuan terbimbing untuk melatih pebelajar menggunakan keterampilan pemecahan masalah yang sudah disiapkan, belajar berdasarkan pengalaman langsung dan menginternalisasikan standar prilaku. Pada tingkatan ketiga dipilih pembelajaran kooperatif tipe investigasi kelompok, dimana pebelajar diberikan kesempatan untuk merencanakan dan melaksanakan penyelidikan untuk memecahkan masalah akademik yang diberikan.

Veenman dkk (2003) menyatakan bahwa para guru/dosen dimungkinkan dan seharusnya lebih memberikan pengarahan atau penjelasan selama fasefase awal pemerolehan pengetahuan, ketika para siswa/mahasiswa bekerja berdasarkan pengetahuan dan keterampilan dasar yang diperlukan untuk memecahkan masalah-masalah kompleks. Sejalan dengan itu, penelitian Klahr dan Nigam (2004) menyimpulkan bahwa pembelajaran langsung sangat efektif untuk mengajarkan keterampilan dasar atau prosedur dasar untuk penyelidikan ilmiah awal.

Pembelajaran yang lebih berorientasi pada peserta didik akan efektif pelaksanaannya jika pengetahuan dan keterampilan-keterampilan dasar yang diperlukan telah dikuasai oleh para siswa/mahasiswa. Akinbobola \& Afolabi (2009) memberikan rekomendasi kepada para guru fisika untuk menerapkan pembelajaran penemuan terbimbing karena mampu melibatkan siswa/mahasiswa dalam aktivitas pemecahan masalah, belajar mandiri, berpikir kritis dan pemahaman, belajar kreatif, dan tidak sekedar belajar hafalan. Veenman dkk (2003) dalam penelitian yang lain menyatakan bahwa untuk mengaktifkan siswa/mahasiswa dalam proses pembelajaran, guru/dosen bisa menerapkan pembelajaran kooperatif dan atau memanfaatkan berbagai teknik diskusi di dalam kelas.

Topik listrik dinamis pada mata kuliah fisika dasar terdiri dari (a) sejumlah pengetahuan deklaratif pada bagian-bagian awal, menyangkut konsep dan prinsipprinsip dasar kelistrikan, serta (b) keterampilan prosedural yang menyangkut keterampilan menggunakan alat ukur kelistrikan dan pemecahan masalah akademik melalui keterampilan proses sains. Pembahasan topik listrik dinamis berikutnya adalah tentang karakteristik dari rangkaian listrik arus searah dan perumusan hukum Ohm yang akan lebih menarik perhatian mahasiswa jika dipelajari melalui proses penyelidikan. Bagian akhir topik adalah penerapan, yakni rangkaian $\mathrm{RC}$ dalam arus searah yang juga sangat mungkin untuk diselidiki melalui kegiatan eksperimen.

Peneliti melihat adanya kesesuaian antara masalah yang dihadapi, karakteristik mahasiswa, karakteristik materi ajar serta kondisi perkuliahan inovatif berdasarkan tingkat otonomi pebelajar. Minimnya aktivitas di kelas yang berimplikasi pada rendahnya kompetensi mahasiswa dapat diselesaikan dengan memberikan otonomi kepada mahasiswa secara bertahap agar lebih aktif dalam proses pemerolehan pengetahuan. Oleh karena itu, peneliti mengajukan alternatif solusi pemecahan masalah yang dihadapi 
dosen dan mahasiswa dalam perkuliahan fisika dasar di PMIPA FKIP Unlam, dengan mengembangkan perangkat perkuliahan inovatif berdasarkan tingkat otonomi pebelajar.

\section{METODE PENELITIAN}

Penelitian ini termasuk penelitian pengembangan (Developmental Research) karena mengembangkan perangkat perkuliahan inovatif berdasarkan tingkat otonomi pebelajar pada perkuliahan Fisika Dasar II topik listrik dinamis. Perangkat perkuliahan tersebut meliputi (1) Rencana Pelaksanaan Perkuliahan (RPP), (2) Materi Ajar (MA), (3) Lembar Kegiatan Mahasiswa (LKM) dan (4) Lembar Penilaian Hasil Belajar (LPHB).

Subjek dari penelitian ini adalah perangkat perkuliahan inovatif berdasarkan tingkat otonomi pebelajar yang dikembangkan oleh peneliti dan selanjutnya mahasiswa yang dijadikan subjek uji coba perangkat, yakni mahasiswa program studi Pendidikan Fisika Jurusan Pendidikan MIPA-FKIP Universitas Lambung Mangkurat yang memprogramkan mata kuliah Fisika Dasar II pada tahun akademik 2013-2014.

Model pengembangan perangkat perkuliahan yang digunakan mengacu pada model Dick and Carey (1994) yang diadaptasi dengan menambahkan tahap validasi perangkat. Selanjutnya, Rancangan penelitian yang digunakan adalah One Group Pretest-Posttest Design.

Instrumen yang digunakan untuk mengumpulkan data meliputi: (1) Lembar Penilaian Perangkat Perkuliahan, (2) Lembar Keterlaksanaan RPP, (3) Lembar Pengamatan Aktivitas Mahasiswa, (4) Lembar Penilaian Hasil Belajar (LPHB), (5) Angket Respon Mahasiswa (ARM), dan (6) Lembar Catatan Kendala Lapangan (LCKL).

Pengumpulan data dilakukan dengan beberapa teknik. Observasi/pengamatan digunakan memperoleh data keterlaksanaan RPP, aktivitas mahasiswa, hasil belajar afektif dan hasil belajar psikomotorik. Teknik tes tertulis digunakan untuk memperoleh data hasil belajar kognitif mahasiswa. Angket digunakan untuk memperoleh data tentang respon berupa minat dan motivasi mahasiswa dalam mengikuti proses perkuliahan. Untuk data validitas perangkat perkuliahan diperoleh dari hasil penelaahan pakar/ahli.

Analisis data dilakukan secara deskriptif sebagai berikut:

1. Data penilaian perangkat perkuliahan dianalisis dengan merata-ratakan skor dari setiap komponen penilaian. Validitas ditentukan dengan membandingkan skor rata-rata dengan kriteria yang telah ditentukan.

2. Data keterlaksanaan RPP dianalisis dengan cara merata-ratakan skor pelaksanaan setiap tahapan/sintaks model pembelajaran yang digunakan.

3. Data aktivitas mahasiswa dianalisis dengan cara membuat tabulasi dari setiap jenis aktivitas, serta menghitung persentase dari setiap aktivitas tersebut.

4. Data hasil belajar mahasiswa berupa kognitif, afektif dan psikomotorik digabung dengan proporsi masing-masing: 50\% kognitif, $20 \%$ afektif dan 30\% psikomotorik untuk mengetahui ketuntasan hasil belajar mahasiswa serta ketuntasan indikator ketercapaian KD yang telah ditetapkan.

5. Data respon berupa minat dan motivasi mahasiswa terhadap perkuliahan dengan perangkatnya, dianalisis dengan cara merata-rata skor setiap aspek, selanjutnya disesuaikan dengan tabel pengkategorian yang ditetapkan.

\section{HASIL PENELITIAN DAN DISKUSI}

Penelitian ini merupakan penerapan konsep scaffolding dalam perkuliahan, yakni pemberian sejumlah besar bantuan kepada mahasiswa selama tahap-tahap awal pembelajaran dan kemudian secara perlahan memberikan/mengalihkan tanggung jawab yang semakin besar itu setelah mereka dapat melakukannya (Slavin, 2006). Pemberian bantuan yang semakin dikurangi ini diikuti dengan perubahan model pembelajaran yang digunakan sebagaimana dikemukakan oleh Howe \& Jones (1993), dalam rangka memberikan otonomi yang lebih luas kepada mahasiswa.

\section{A. Validitas perangkat perkuliahan}

Rencana pelaksanaan perkuliahan yang dikembangkan dalam penelitian ini memberikan penekanan pada peran/tanggung jawab yang semakin besar kepada mahasiswa agar bisa menjadi pebelajar yang mandiri. Hal ini sejalan dengan teori konstruktivis, dimana peserta didik diharapkan memiliki kemampuan untuk mengkonstruksi sendiri pengetahuannya melalui pengalaman langsung.

Lembar kegiatan mahasiswa disusun secara sistematis berdasarkan tingkat kemampuan mahasiswa, dengan kata lain bahwa tingkat kesulitannya disesuaikan dengan pengalaman belajar mahasiswa. Toharuddin (2011) menyatakan bahwa LKS/LKM sains yang baik adalah yang tersusun secara logis, sistematis, dan sesuai dengan tingkat kemampuan serta perkembangan peserta didik. Selain itu, LKM/LKS juga harus dapat merangsang dan memotivasi keingintahuan peserta didik, mengembangkan keterampilan proses sains serta kemampuan memecahkan masalah (problem solving).

Lembar penilaian hasil belajar yang dikembangkan dalam penelitian ini berupa tes untuk 
mengukur kognitif, serta lembar pengamatan untuk mengukur afektif dan psikomotorik mahasiswa. Hal ini sejalan dengan amanah undang-undang yang tidak hanya menitikberatkan penilaian pada aspek kognitif saja, tetapi penting pula untuk mengukur hasil belajar aspek afektif dan psikomotorik.

Penilaian hasil belajar yang dikembangkan oleh peneliti didasarkan pada kompetensi yang harus dimiliki oleh seorang calon guru fisika SMA. Kompetensi tersebut sejalan dengan indikator literasi sains dan teknologi yang diharapkan dimiliki mahasiswa/lulusan dari bidang studi pendidikan fisika sebagai calon guru, yaitu: (1) kemampuan memahami konsep, prinsip dan atau teori/hukum dasar fisika, (2) kemampuan mengaplikasikan rumus fisika berdasarkan data/pengamatan, (3) kemampuan memformulasikan fenomena fisika, (4) kemampuan menyelesaikan fenomena/gejala fisika dalam kehidupan sehari-hari, (5) kemampuan merancang dan melakukan kegiatan eksperimen fisika.

Perhitungan reliabilitas memakai rumus Alpha Cronbach dengan bantuan program SPSS 16.0 juga menunjukkan bahwa reliabilitas tes hasil belajar kognitif sebesar 0,787 yang termasuk dalam derajat reliabilitas sedang. Selanjutnya dari analisis sensitivitas butir soal, kesemua butir soal kognitif yang dikembangkan berkategori sensitif atau peka terhadap efek-efek perkuliahan. Hal ini didasarkan pada perolehan nilai koefisien sensitivitas butir soal yang kesemuanya lebih besar dari 0,3.

Secara umum perangkat perkuliahan yang dikembangkan berkategori baik, sehingga dinyatakan valid dan layak untuk diujicobakan di kelas, sebagaimana hasil penelaahan pakar yang diringkas pada Tabel 1.

Tabel 1. Hasil Validasi Perangkat Perakuliahan

\begin{tabular}{|l|c|c|}
\hline \multirow{2}{*}{$\begin{array}{c}\text { Jenis Perangkat } \\
\text { Perkuliahan }\end{array}$} & \multicolumn{2}{c|}{ Hasil Penilaian } \\
\cline { 2 - 3 } & Kategori & Reliabilitas \\
\hline RPP & Baik & $99,50 \%$ \\
\hline Materi Ajar & Baik & $99,33 \%$ \\
\hline LKM & Baik & $98,96 \%$ \\
\hline LPHB & Baik & $97,91 \%$ \\
\hline
\end{tabular}

\section{B. Keterlaksanaan RPP}

Keterlaksanaan RPP memperlihatkan hasil yang sangat baik pada ketiga pertemuan, walaupun masih terdapat beberapa kelemahan dalam tataran pelaksanaan. Kelemahan tersebut utamanya dalam hal pengelolaan waktu dan kemampuan dasar mahasiswa.

Pada pertemuan pertama keterlaksanaan RPP adalah $100 \%$ dan hampir seluruh fase/tahapan pembelajaran langsung telah dilaksanakan dengan kategori sangat baik (skor keterlaksanaan lebih dari 4,2) sebagaimana yang terlihat pada Gambar 1.

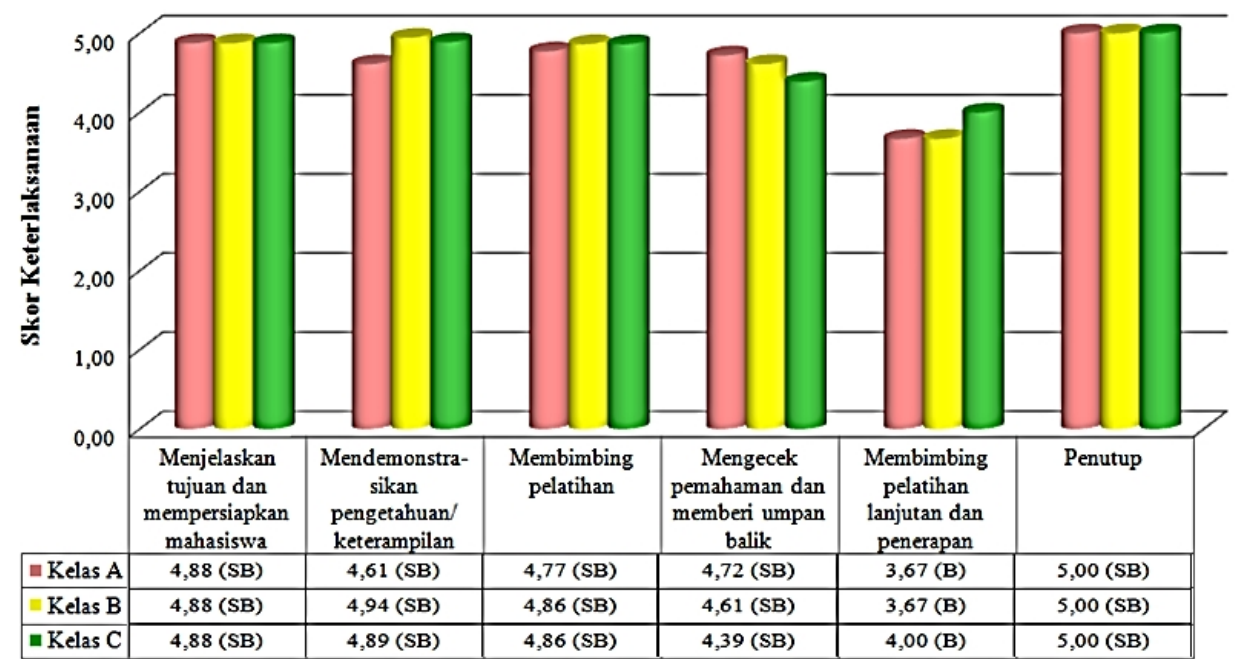

Gambar 1. Grafik Keterlaksanaan RPP pada Pertemuan Pertama dengan Model Pembalajaran Langsung

Kurang maksimalnya pelaksanaan fase membimbing pelatihan lanjutan dan penerapan sehingga masih berkategori baik lebih disebabkan oleh faktor waktu. Pelaksanaan fase-fase sebelumnya yang agak molor mengisyaratkan agar dosen sekaligus sebagai peneliti berupaya untuk lebih selektif dalam memilih pokok-pokok penting dari informasi/penjelasan yang disampaikan kepada mahasiswa, menginformasikan waktu yang disiapkan untuk melakukan persiapan, pelaksanaan dan analisis hasil eksperimen,serta mengingatkan sisa waktu yang tersedia pada saat eksperimen berlangsung.

Berdasarkan Gambar 2 diketahui bahwa keterlaksanaan RPP-02 adalah sebesar 100\% dengan kualitas keterlaksanaan berkategori sangat baik karena skor rata-rata perolehan untuk setiap tahap lebih besar dari 4,2 (batas bawah kategori sangat baik). Untuk 
meminimalisasi potensi munculnya kendala di lapangan, maka peneliti memastikan prasyarat pengetahuan bagi mahasiswa utamanya yang berkaitan dengan penggunaan alat ukur, serta memberikan prioritas penyelidikan bagi setiap kelompok. Eksperimen yang tidak menjadi kewajiban bagi kelompok di kelas diselesaikan di luar jam perkuliahan sebagai tugas terstruktur.

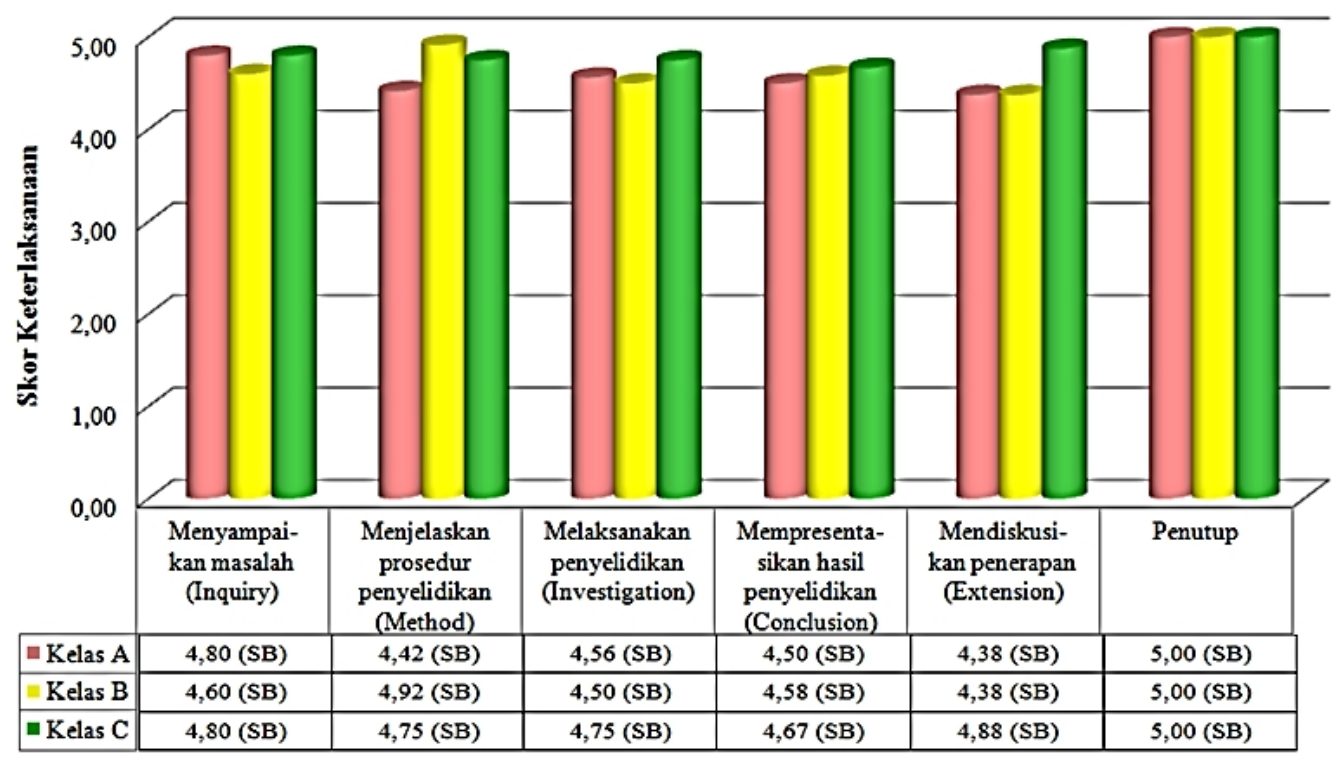

Gambar 2. Grafik Keterlaksanaan RPP pada Pertemuan Kedua dengan Model Pembelajaran Penemuan Terbimbing

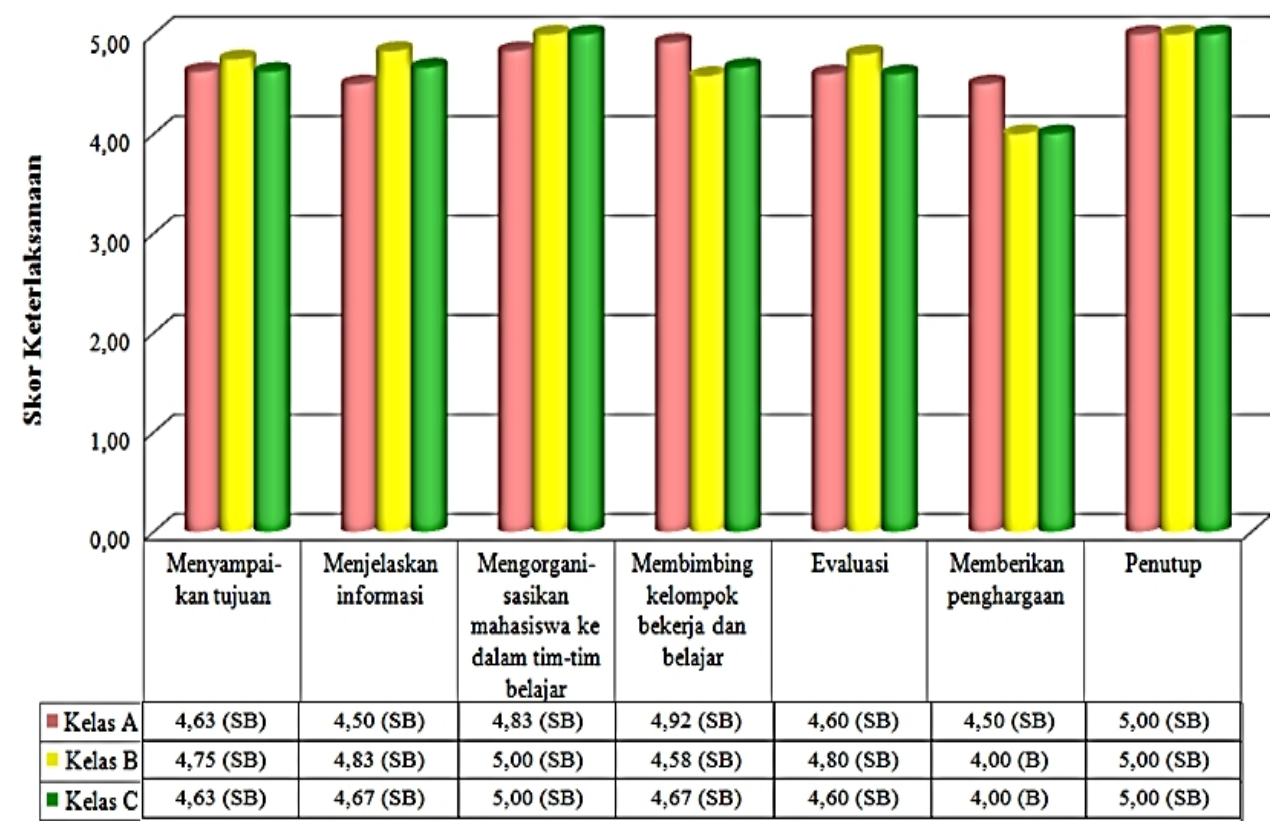

Gambar 3. Grafik Keterlaksanaan RPP pada Pertemuan Ketiga dengan Model Pembelajaran Kooperatif tipe Investigasi Kelompok

Keterlaksanaan RPP untuk pertemuan ketiga (Gambar 3) lebih baik dari dua pertemuan sebelumnya, khususnya dalam hal pengelolaan waktu. Ketidakbiasaan mahasiswa dalam menyusun prosedur kerja secara mandiri sempat mempengaruhi pengalokasian waktu yang direncanakan. Namun dengan bimbingan yang intensif, akhirnya mahasiswa mampu menyelesaikan tugas yang diberikan dan selanjutnya mempresentasikannya di depan kelas. Secara umum keterlaksanaan RPP pada pertemuan ketiga ini berkategori sangat baik. 


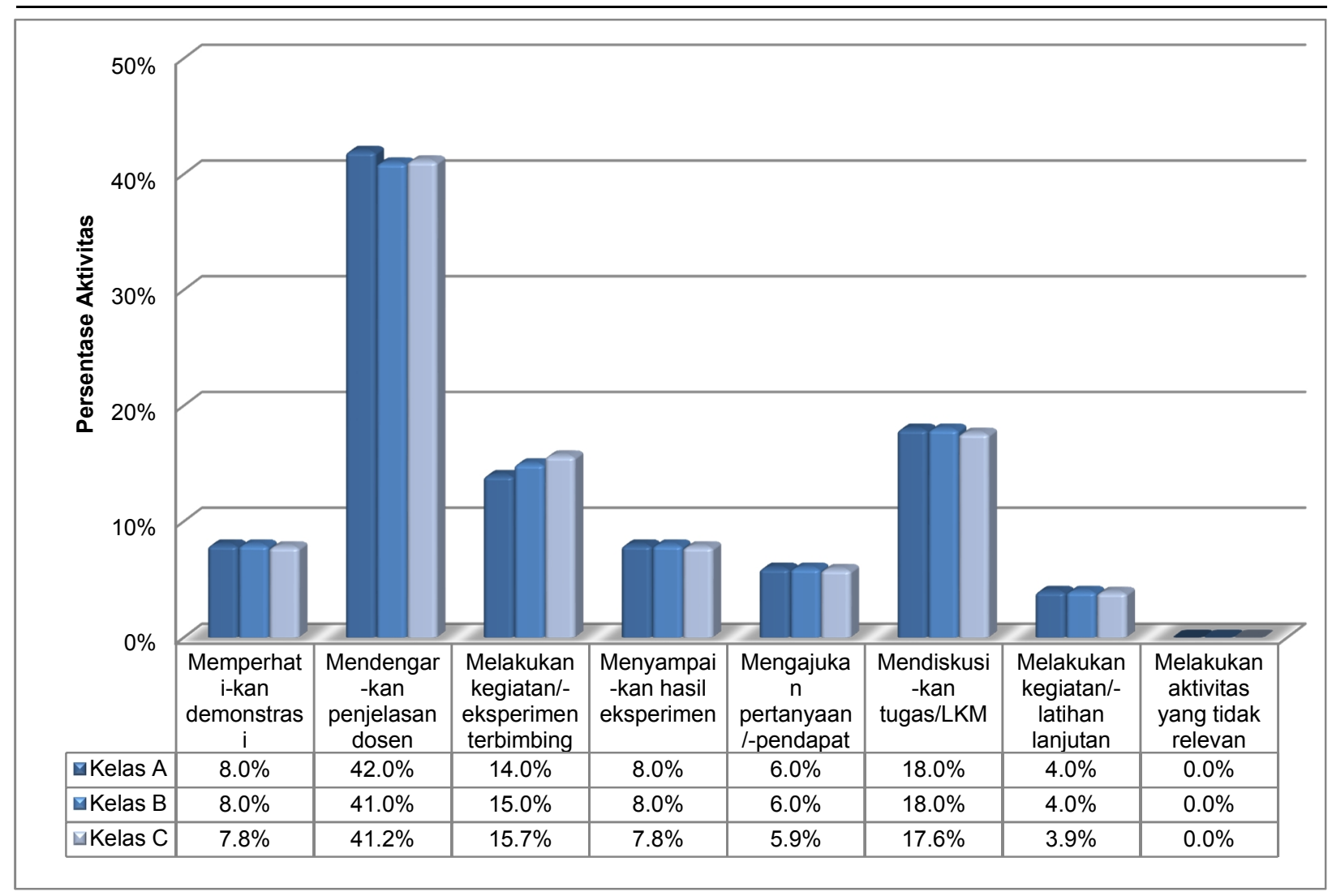

Gambar 4. Grafik Aktivitas Mahasiswa pada Pertemuan Pertama

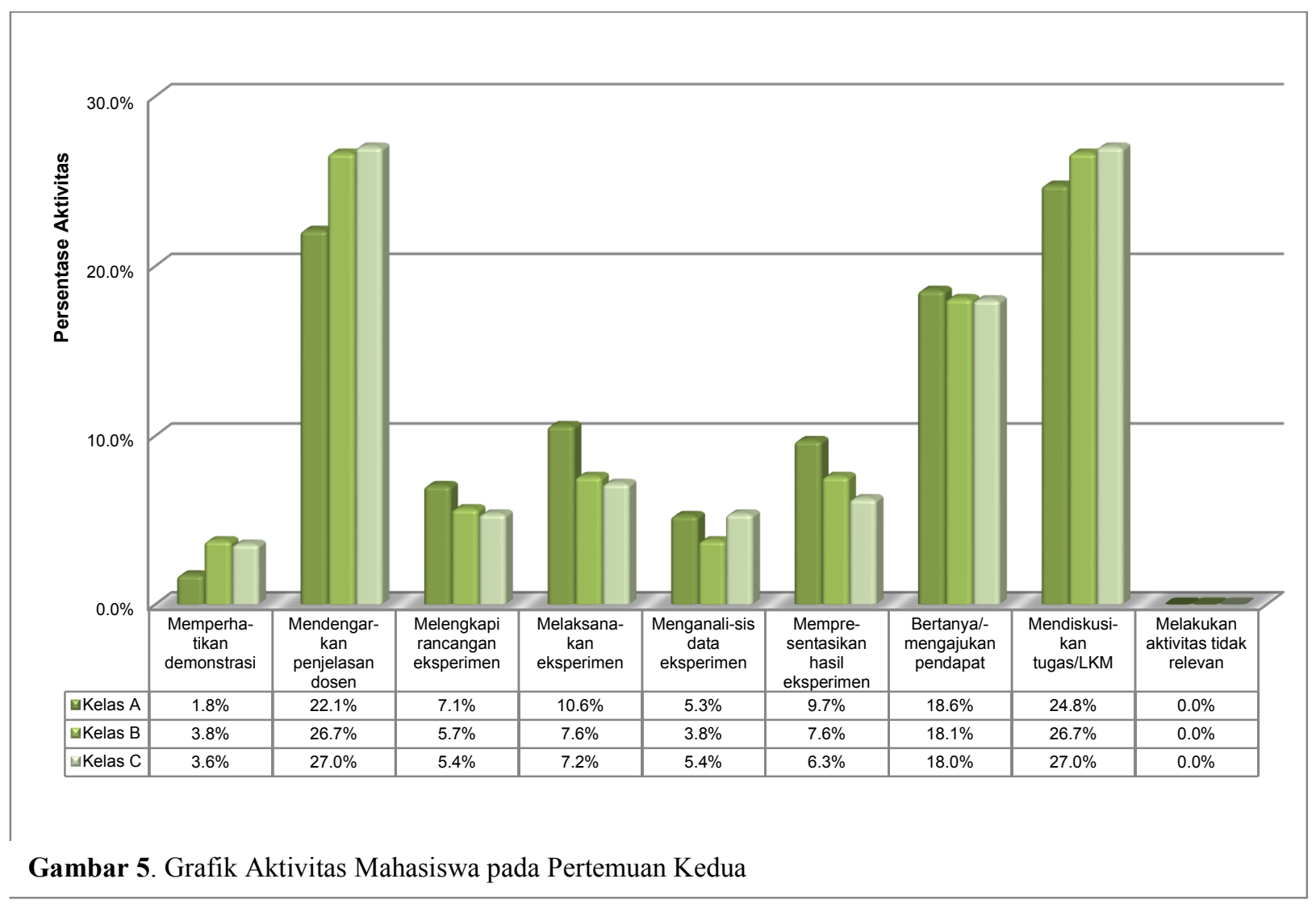




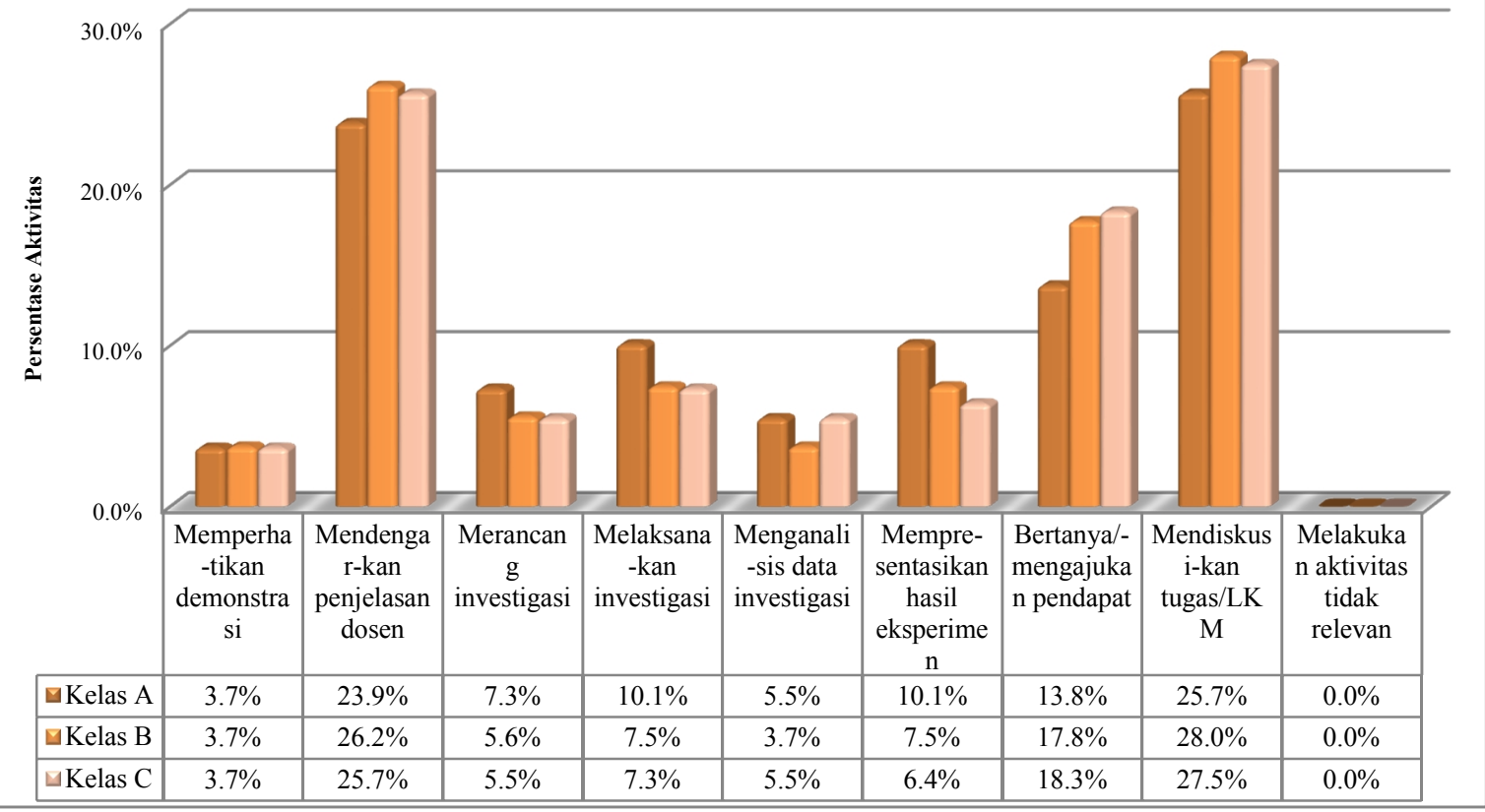

Gambar 6. Grafik Aktivitas Mahasiswa pada Pertemuan Ketiga

\section{Aktivitas Mahasiswa}

Aktivitas mahasiswa yang dominan pada pertemuan pertama sebagaimana yang terlihat pada Gambar 4. adalah mendengarkan penjelasan dosen memperhatikan penjelasan dan demonstrasi oleh dosen. Aktivitas dominan berikutnya adalah mendiskusikan tugas/LKM dan melakukan kegiatan/eksperimen terbimbing. Pembelajaran langsung adalah sebuah model pembelajaran yang berpusat pada pengajar (guru/dosen). Sebagaimana hasil penelitian Vennman dkk (2003), fase-fase awal pembelajaran langsung memposisikan peserta didik pada posisi yang agak pasif, namun setelah itu menuntut keaktifan peserta didik.

Aktivitas mendiskusikan tugas/LKM menjadi aktivitas paling dominan yang dilakukan oleh mahasiswa pada pertemuan kedua walaupun hanya memiliki perbedaan yang sangat tipis dengan aktivitas mendengarkan penjelasan dosen. Secara umum, aktivitas mahasiswa pada pertemuan kedua (Gambar 5) ini telah mengikuti tuntutan dari model pembelajaran penemuan terbimbing. Penemuan terbimbing merupakan model pembelajaran yang memberikan otonomi menengah kepada mahasiswa dan diharapkan menjadi jembatan penghubung antara teacher centered menuju student centered. Aktivitas lain yang dilakukan oleh mahasiswa adalah bertanya/mengemu-kakan pendapat, melaksanakan eksperimen serta mempresentasikan hasilnya.

Pertemuan ketiga dengan model koperatif tipe investigasi kelompok menuntut mahasiswa untuk lebih aktif dengan beban tugas yang lebih berat dari pada sebelumnya. Setiap kelompok harus merancang eksperimen sendiri untuk menyelidiki hubungan antara tegangan dan waktu serta kuat arus dan waktu pada proses pengisian dan pengosongan muatan kapasitor. Hal ini mengakibatkan meningkatnya persentase kegiatan mendiskusikan tugas dan menjadi aktivitas paling dominan di kelas, diikuti oleh aktivitas mendengarkan penjelasan dosen dan aktivitas bertanya/mengajukan pendapat.

Deskripsi aktivitas mahasiswa diatas bisa dikatakan telah menunjukkan adanya kesesuaian antara tuntutan setiap model pembelajaran dengan aktivitas yang dilakukan oleh mahasiswa. Perangkat perkuliahan berdasarkan tingkat otonomi peserta didik mampu meningkatkan aktivitas dan tanggung jawab mahasiswa di dalam proses belajar mengajar. Hal ini sejalan dengan temuan penelitian oleh Suyidno (2010) dan sangat mendukung pandangan beberapa ahli pendidikan yang menyatakan bahwa dalam kegiatan belajar, subjek didik harus berbuat aktif. Tanpa adanya aktivitas, maka proses belajar tidak mungkin berlangsung dengan baik. (Sardiman, 2010:97)

\section{Hasil Belajar Mahasiswa}

Implementasi perangkat perkuliahan berdasarkan tingkat otonomi pebelajar dengan menggunakan tiga model pembelajaran merupakan sebuah urutan yang didasarkan pada analisis kebutuhan. Model pembelajaran langsung sebagai wujud dari otonomi tingkat I merupakan dasar pijakan untuk dapat melangkah ke pembelajaran penemuan terbimbing 
(otonomi tingkat II) dan selanjutnya ke pembelajaran kooperatif tipe investigasi kelompok (otonomi tingkat III). Hasil-hasil belajar dari setiap tingkat otonomi (berupa pengetahuan dan keterampilan yang salah satunya diwujudkan dalam aktivitas mahasiswa selama proses perkuliahan) merupakan prasyarat untuk memasuki tingkat otonomi berikutnya. Oleh karena itu, evaluasi dari tiap tingkat otonomi diperlukan untuk memastikan kesiapan dari mahasiswa menuju tingkat otonomi berikutnya.

Gambar 7 menunjukkan rata-rata hasil belajar mahasiswa sebelum dan setelah mengikuti perkuliahan yang menerapkan perangkat perkuliahan berdasarkan tingkat otonomi pebelajar yang dikembangkan. Hasil posttest untuk ketiga kelas uji coba sama-sama memperlihatkan peningkatan nilai rata-rata dari hasil pretest. Selain itu, peningkatan yang relatif sama juga terlihat dari nilai rata-rata posttest dari pertemuan pertama menuju pertemuan kedua dan ketiga.

Ketuntasan hasil belajar mahasiswa pada pertemuan pertama merupakan modal awal yang diperlukan menuju otonomi tingkat II dan III. Untuk dapat menerapkan perkuliahan yang lebih berorientasi pada peserta didik (pebelajar), maka mahasiswa perlu untuk menguasai pengetahuan dan keterampilan dasar penyelidikan (Veenmann, 2003). Penguasaan konsepkonsep dasar kelistrikan dan keterampilan proses sains ini menjadi prasyarat berlangsungnya kegiatan penyelidikan pada pertemuan kedua dalam setting pembelajaran penemuan terbimbing dan pertemuan ketiga dengan pembelajaran kooperatif tipe investigasi kelompok. Selain berhasil memberikan ketuntasan secara individu, perkuliahan berdasarkan tingkat otonomi pebelajar juga berhasil menuntaskan seluruh indikator ketercapaian Kompetensi Dasar (KD).

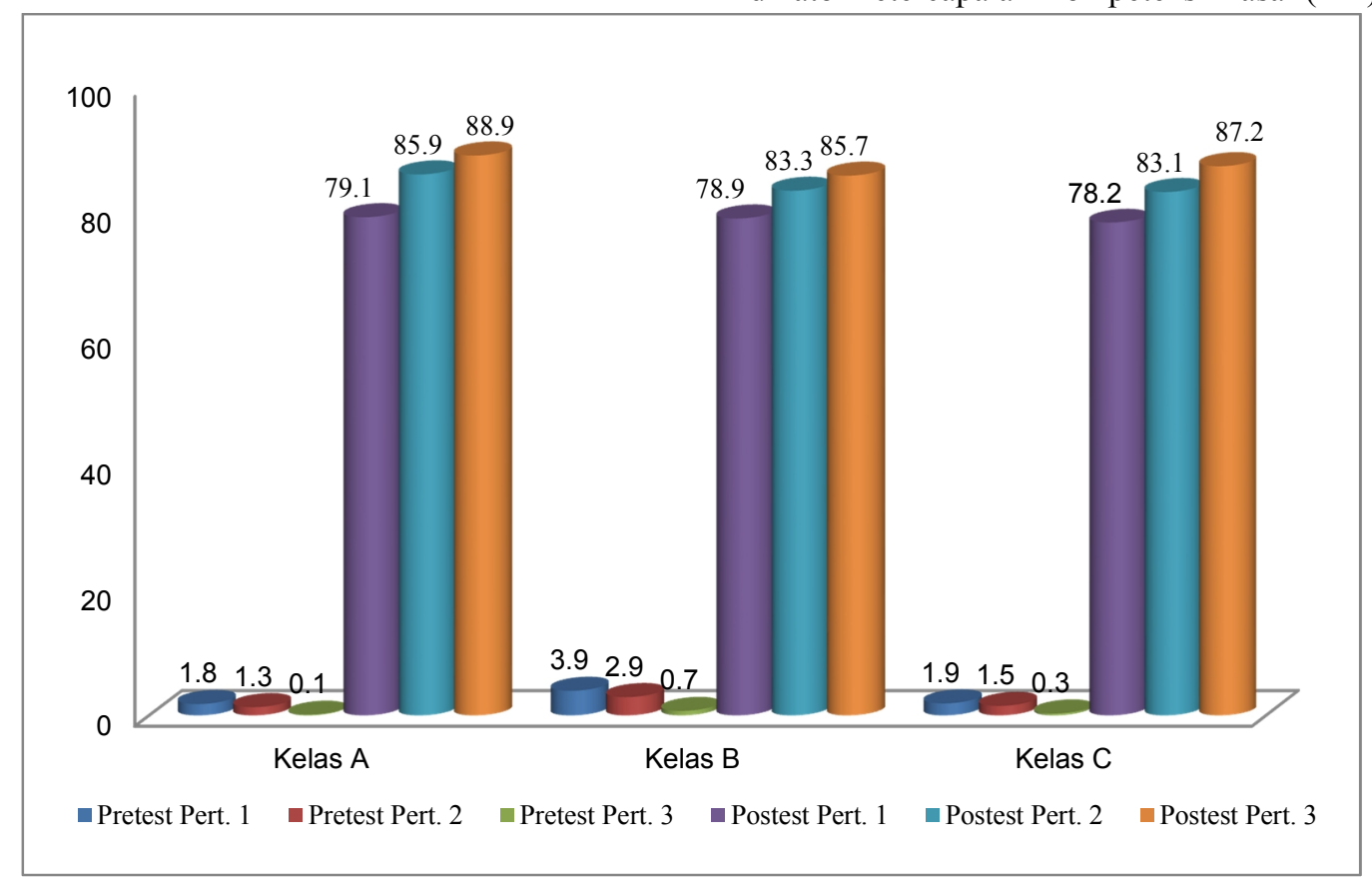

Gambar 7. Grafik Rekapitulasi Nilai Rata-Rata Pretest dan Posttest mahasiswa untuk Ketiga Pertemuan

\section{E. Respon Mahasiswa}

Respon mahasiswa terhadap perkuliahan berdasarkan tingkat otonomi pebelajar diukur menggunakan angket respon berupa minat dan motivasi ARCS. Minat dan motivasi mahasiswa terhadap kegiatan perkuliahan sebagaimana Gambar 8 rata-rata berkategori baik. Hal ini menunjukkan bahwa perangkat perkuliahan berdasarkan tingkat otonomi pebelajar yang dikembangkan pada perkuliahan fisika dasar topik listrik dinamis dapat menumbuhkan minat dan motivasi mahasiswa dalam melaksanakan/mengikuti kegiatan perkuliahan ditinjau dari aspek perhatian, relevansi, kepercayaan diri dan kepuasan. Menurut Ainley dkk (Woolfolk, 2009). minat personal maupun minat situasional berhubungan dengan belajar dari teks. Minat yang lebih besar menghasilkan respons emosional yang lebih positif terhadap materi perkuliahan, lalu menghasilkan persistensi yang lebih tinggi, pemrosesan yang lebih mendalam, ingatan yang lebih baik terhadap materi, dan prestasi yang lebih tinggi. Hal ini mengisyaratkan kepada para pendidik untuk lebih terampil dalam menyusun teks/bahan ajar yang mampu membangkitkan minat peserta didiknya 


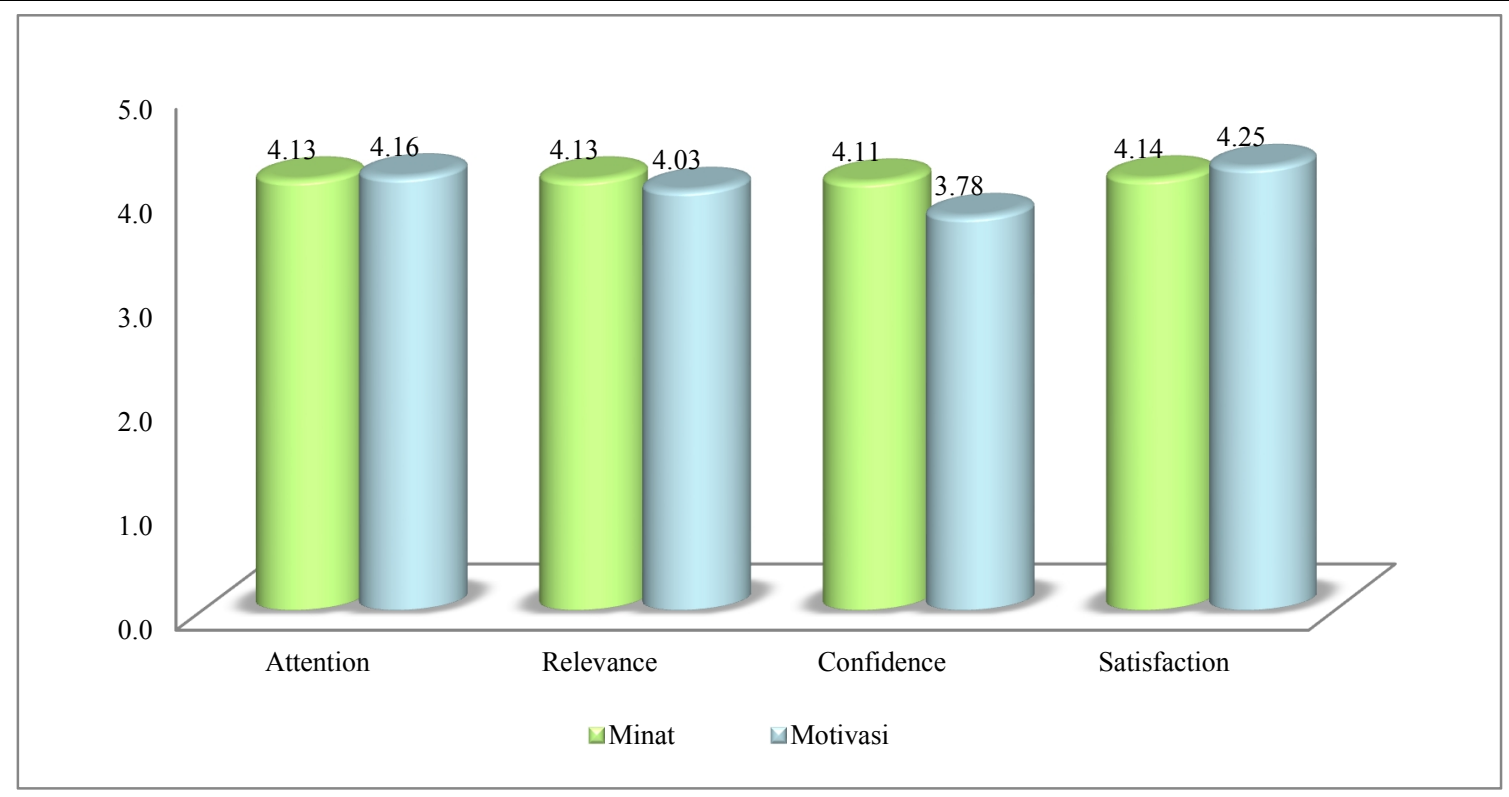

Gambar 8. Grafik Respon Minat dan Motivasi Mahasiswa terhadap Perkuliahan

Selain dari hasil angket minat dan motivasi ARCS, respon mahasiswa yang baik terhadap pembelajaran dapat pula kita lihat dari keaktifan mahasiswa dalam proses pembelajaran, khususnya dalam melakukan kegiatan eksperimen. Keingintahuan mahasiswa tersebut bahkan mendorongnya untuk berlatih di laboratorium di luar jam kuliah yang ditetapkan.

Minat dan motivasi yang tinggi berdampak pada hasil belajar mahasiswa yang juga mengalami peningkatan perolehan nilai rata-rata uji akhir (posttest). Menurut Sardiman (2010) prinsip dan hukum pertama dalam kegiatan pendidikan dan pengajaran adalah seseorang akan berhasil dalam belajar kalau pada dirinya sendiri ada keinginan atau dorongan untuk belajar (motivasi). Penelitian oleh Wigfield, Eccles dan Rodrigues (Slavin, 2006) lebih lanjut menyatakan bahwa keberhasilan (pencapaian hasil belajar) dan motivasi saling berpengaruh satu sama lain. Keberhasilan akan memunculkan motivasi untuk memunculkan keberhasilan berikutnya.

\section{KESIMPULAN}

\section{A. Simpulan}

Berdasarkan analisis dan diskusi hasil penelitian, dapat disimpulkan bahwa perangkat perkuliahan inovatif berdasarkan tingkat otonomi pebelajar yang dikembangkan telah layak (valid, praktis, dan efektif) untuk digunakan pada perkuliahan fisika dasar.

\section{B. Saran}

Pengembangan perangkat perkuliahan inovatif berdasarkan tingkat otonomi pebelajardapat digunakan pada perkuliahan fisika dasar

\section{REFERENSI}

Akinbobola, A.O. and Afolabi, F. (2009). "Constructivist Practices Through Guided Discovery Approach: The Effect On Students' Cognitive Achievements In Nigerian Senior Secondary School Physics". Bulgarian Journal of Science and Education Policy. Vol. 3 No. 2. pp 233-252.

Alonso, M. and Finn, E. J. (1983). Fundamental University Physics. Sidney : Addison- Wesley Publ. Co, Reading.

Anderson, L.W. and Krathwhol, D.R. (2001). A Taxonomy for Learning, Teaching, and Assessing; A Revision of Bloom's Taxonomy of Educational Objectives. New York : Addison Wesley Longman, Inc.

Arends, R.I. (2012). Learning to Teach. $9^{\text {th }}$ edition. New York: McGraw-Hill Companies.

Balim, A.G. (2009). "The Effects of Discovery Learning on Students' Success and Inquiry Learning Skills". Eurasian Journal of Educational Research. Issue 35. Spring pp 120.

Borich, G.D. (1994). Observation Skills for Effectivness Teaching. New York: Macmillan Company, Inc.

Dick, W. and Carey, L. (2009). The Systematic Design of Instruction. $7^{\text {th }}$ ed. New Jersey: Pearson

Direktorat Jenderal Pendidikan Tinggi, Depdikbud. (1991). Kurikulum Pendidikan MIPA-LPTK Program Strata-1 (S1). Jakarta.

Doymus, K., Simsek, U., Karacop, A., and Ada, S. (2009). "Effects of Two Cooperative Learning Strategies on Teaching and Learning Topics of 
Thermochemistry". World Applied Sciences Journal. Vol. 7 No. 1. pp. 34-42.

Howe, A. C. and Jones, L. (1993). Engaging Children in Science. New York: Macmillan College Publishing Company.

Ibrahim, M. (2010). Dasar-Dasar Proses Belajar Mengajar. Surabaya: Unesa University Press.

Jabr, R.K. 2011. "Introducing The Skills of Selfassessment and Peer Feedback". Studies in Self-Access Learning Journal. Vol. 2 No. 1. pp 26-31.

Jamal, M. A. (2010). Pengembangan Teknik Pemodelan Fisika melalui Pengajaran Langsung pada Perkuliahan Fisika Dasar. Tesis Magister Pendidikan tidak dipublikasikan: Pascasarjana Unesa.

Kardi, S. (2003). "Strategi Motivasi Model ARCS". Bahan kuliah pada Prodi S2 Pendidikan Sains Unesa Surabaya.

Kemp, J.E. (1994). Designing Effective Instruction. New York: Macmillan College Publishing Company.
Klahr, D. and Nigam, M. (2004). "The Equivalence of Learning Paths in Early Science Instruction: Effects of Direct Instruction and Discovery Learning". Psycological Science. Vol. 15 No. 10. pp 661-667.

Koc, Y. , Doymus, K., Karacop, A., Simsek, U. (2010). "The Effects of Two Cooperative Learning Strategies on the Teaching and Learning of the Topics of Chemical Kinetics". Journal of Turkish Science Education. Vol. 7, Issue 2.

Magliaro, S.G., Lockee, B.B., and Burton, J.K. (2005). "Direct Instruction Revisited: A Key Model for Instructional Technology". Educational Technology Research \& Development. Vol. 53 No. 4. pp 41-55.

Mitchell, M.G., Montgomery, H., Holder, M., and Stuart, D. (2008). "Group Investigation as a Cooperative Learning Strategy: An Integrated Analysis of the Literature". The Alberta Journal of Educational Research. Vol. 54 No. 4. pp 388-395. 